\begin{tabular}{|l|l|l|}
\hline \multicolumn{2}{|c|}{ PublisherInfo } \\
\hline \hline PublisherName & $:$ & BioMed Central \\
\hline \hline PublisherLocation & $:$ & London \\
\hline \hline PublisherImprintName & $:$ & BioMed Central \\
\hline \hline
\end{tabular}

\title{
Percutaneous needle aspiration for diagnosis of pulmonary infection
}

\begin{tabular}{|l|l|l||}
\hline \multicolumn{2}{|c|}{ ArticleInfo } \\
\hline \hline ArticleID & $:$ & 4213 \\
\hline \hline ArticleDOI & $:$ & $10.1186 /$ ccf-2000-5658 \\
\hline \hline ArticleCitationID & $:$ & 5658 \\
\hline \hline ArticleSequenceNumber & $:$ & 72 \\
\hline \hline ArticleCategory & $:$ & Paper Report \\
\hline ArticleFirstPage & $:$ & 1 \\
\hline \hline ArticleLastPage & $:$ & 3 \\
\hline \hline & & RegistrationDate : 2000-6-30 \\
\hline ArticleHistory & $:$ & OnlineDate \\
\hline \hline ArticleCopyright & $:$ & Current Science Ltd2000-6-30 \\
\hline \hline ArticleGrants & $:$ & \\
\hline \hline ArticleContext & $:$ & 1305422 \\
\hline \hline
\end{tabular}




\section{Keywords}

CT guided percutaneous needle aspiration, immunocompromise, pulmonary infection

\section{Comments}

Although not specifically studying intensive care unit (ICU) patients, this paper is of interest as it describes a novel method of obtaining bacteriological samples. The yield of this study was much higher than in previously published series ( $79.2 \%$ versus $42-44 \%)$, this may be due to the use of empirical antibiotic therapy. If this is the case it may limit the application to patients with a very high level of antibiotic exposure. In this study, however, there was no correlation between antibiotic therapy and aspiration yield. Most noticeably the complication rate of this procedure was very low. Open lung biopsy carries a $8-20 \%$ complication rate whereas CT guided needle aspiration carries a $1.1 \%$ complication rate. The yield of the two techniques is similar (at least in this series). It appears that CT guided needle aspiration may have an application to obtaining a definitive diagnosis in ICU patients with pulmonary infection.

\section{Introduction}

Pulmonary infections are a common cause of morbidity in immunocompromised patients. The use of empirical treatment can be potentially hazardous and so a bacterial diagnosis is of great benefit. Techniques such as bronchoalveolar lavage (BAL) and nasopharyngeal aspiration may produce contaminated samples and are difficult in nonintubated patients. Open lung biopsy is sometimes employed for diagnosis but has a high complication rate (8-20\%). CT guided percutaneous needle biopsy has not been previously studied in advancing the microbiological diagnosis in such patients.

\section{Methods}

\section{- Retrospective review of 21 patients (24 procedures)}


- Target lesion located with local anaesthesia, a 20G needle under CT guidance

- Aspirated material visually inspected and aspirate repeated if sample appeared inadequate

- Cytologic evaluation and culture for aerobic and anaerobic bacteria, Mycobacterium sp and fungi were performed

- Presence and duration of empiric antibiotic therapy prior to investigation was recorded

- Patients were assigned to positive and negative yield groups

\section{Results}

Identification of one or more species of pathogens was made in 19 of 24 samples $(79.2 \%)$ Five aspirates yielded mixed inflammatory cells and had no bacterial or fungal growth.Bacteria isolated included Staphyloccus aureus (4), Mycobacterium tuberculosis (3), Pseudomonas aeruginosa (2), Streptococcus pneumoniae (1) and Klebsiella pneumoniae (1).Fungi isolated were Aspergillus fumigatus (7), Cryptococcus neoformans (1) and Candida albicans(1). Two organisms were found in one patient.A small asymptommatic pneumothorax occurred on one occasion but did not require treatment.

\section{References}

1. Hwang SS, Kim HH, Park SH, Jung JI, Jang HS: The value of CT guided percutaneous needle aspiration in immunocompromised patients with suspected pulmonary infection. Am J Roentgenol. 2000, 175: 235-238.

This PDF file was created after publication. 